\title{
Synergistic effect of Co(II)-hole and Pt-electron cocatalysts for enhanced photocatalytic hydrogen evolution performance of P-doped g- $\mathbf{C}_{3} \mathbf{N}_{4}$
}

\author{
Kouhua Sun a,c, $\dagger$, Jun Shen ${ }^{b, \dagger}$, Qinqin Liu c,d, Hua Tang c,\#, Mingyi Zhang d, Syed Zulfiqar c, \\ Chunsheng Lei ${ }^{a}, *$ \\ a School of Environment \& Safety Engineering, Changzhou University, Changzhou 213164, Jiangsu, China \\ b School of Pharmacy, Suzhou Vocational Health College, Suzhou 215009, Jiangsu, China \\ c School of Materials Science and Engineering, Jiangsu University, Zhenjiang 212013, Jiangsu, China \\ ${ }^{d}$ Key Laboratory for Photonic and Electronic Bandgap Materials, Ministry of Education, Harbin Normal University, Harbin 150025, Heilongjiang, China
}

\section{A R T I C L E I N F}

\section{Article history:}

Received 30 May 2019

Accepted 22 June 2019

Published 5 January 2020

\section{Keywords:}

Photocatalytic $\mathrm{H}_{2}$ production

Hole cocatalyst

Electron cocatalyst

P-doped g- $\mathrm{C}_{3} \mathrm{~N}_{4}$

\begin{abstract}
A B S T R A C T
g- $\mathrm{C}_{3} \mathrm{~N}_{4}$ is a metal-free semiconductor and a potential candidate for photocatalytic $\mathrm{H}_{2}$ production, however, the drawbacks, rapid recombination rate and limited migration efficiency of photogenerated carriers, restrict its photocatalytic activity. Herein, Co(II) as a hole cocatalyst modified P-doped g- $\mathrm{C}_{3} \mathrm{~N}_{4}$ were successfully prepared to ameliorate the separation efficiency of photoinduced carriers and enhance the photocatalytic hydrogen production. The photocatalytic results demonstrated that the P-doped g- $\mathrm{C}_{3} \mathrm{~N}_{4}(\mathrm{PCN})$ exhibited higher photocatalytic activity compared with pure g- $\mathrm{C}_{3} \mathrm{~N}_{4}$, while Co(II)/PCN photocatalyst exhibited further enhancement of photocatalytic performance. The proposed possible mechanism based on various characterizations is that P-doping can modulate the electronic structure of $\mathrm{g}-\mathrm{C}_{3} \mathrm{~N}_{4}$ to boost the separation of photogenerated-e- and $\mathrm{h}^{+}$; while the synergistic effect of both Co(II) (as hole cocatalyst) and Pt (as electron cocatalyst) can not only lead to the directional shunting of photogenerated $\mathrm{e}^{+}-\mathrm{h}^{-}$pairs, but further accelerate the photogenerated electrons transfer to $\mathrm{Pt}$ in order to join the photocatalytic reduction process for hydrogen evolution. As a result, the transportation and separation of photoinduced carriers were accelerated to greatest extent in the $\mathrm{Pt} / \mathrm{Co}(\mathrm{II}) / \mathrm{PCN}$ photocatalyst.
\end{abstract}

(C) 2020, Dalian Institute of Chemical Physics, Chinese Academy of Sciences. Published by Elsevier B.V. All rights reserved.

\section{Introduction}

Technology requirements for a sustainable society lead to the surge of clean and renewable energy research in the 21st century. Compared with other chemical fuels, hydrogen $\left(\mathrm{H}_{2}\right)$ as a new type of clean energy exhibits the highest specific energy of combustion [1-4]. The photocatalytic $\mathrm{H}_{2}$ generation from water splitting based semiconductor technology is proved to be a sustainable solution to resolve the current environmental and energy issues [5-7]. Various semiconductor-based photocatalysts (such as $\mathrm{TiO}_{2}$ [8], $\mathrm{ZnO}$ [9], CdS [10], and g- $\mathrm{C}_{3} \mathrm{~N}_{4}$ [11] etc.) have been developed for the photocatalytic $\mathrm{H}_{2}$-evolution appli-

\footnotetext{
*Corresponding author. Tel: +86-15995017856; E-mail: qiuyu_lei@126.com

\# Corresponding author. E-mail: huatang79@163.com

† These authors contributed equally to this work.

This work was supported by the National Natural Science Foundation of China (51672113) and QingLan Project Foundation of Jiangsu Province (201611).

DOI: S1872-2067(19)63430-3 | http://www.sciencedirect.com/science/journal/18722067 | Chin. J. Catal., Vol. 41, No. 1, January 2020
} 
cation. Among these reported semiconductors, g- $\mathrm{C}_{3} \mathrm{~N}_{4}$, as a new class of nonmetallic organic polymer semiconductor, has attracted huge interest due to inimitable layer structure, suitable energy structure $(2.7 \mathrm{eV})$, simple fabrication and outstanding stability [12-14]. However, single g- $\mathrm{C}_{3} \mathrm{~N}_{4}$ demonstrates low activity owing to the poor utilization of photoexcited charge carriers caused by the weak van der Waals force [15].

A great deal of approaches have been proposed to improve the photocatalytic performance of $\mathrm{g}-\mathrm{C}_{3} \mathrm{~N}_{4}$, for example, liquid exfoliation of bulk g- $\mathrm{C}_{3} \mathrm{~N}_{4}$, surface modification, elemental doping, construction of heterojunction with other semiconductors or loading of co-catalysts [16-22]. Heteroatoms doping (nonmetal elements such as $\mathrm{P}, \mathrm{S}$ and $\mathrm{N}$ etc.) can tune energy bands of semiconductor at atomic level, which not only improves light absorption, but boost photogenerated-carrier separation [23-26]. For example, Guo et al. [27] employed phosphorus acid to fabricate P-doped g- $\mathrm{C}_{3} \mathrm{~N}_{4}$ with hexagonal tubular morphology; Ran et al. [28] prepared P-doped g- $\mathrm{C}_{3} \mathrm{~N}_{4}$ using 2-aminoethylphosphonic acid and melamine as $\mathrm{P}$ source and g- $\mathrm{C}_{3} \mathrm{~N}_{4}$ precursor, respectively; and Bellardita and coauthors [29] synthesized P-doped g- $\mathrm{C}_{3} \mathrm{~N}_{4}$ using $\mathrm{NH}_{4} \mathrm{H}_{2} \mathrm{PO}_{4}$ as $\mathrm{P}$ source. For enhancing the photocatalytic activity, cocatalyst is considered more efficient to speed up the transportation an separation of photoinduced carriers [30,31]. Usually, the photocatalytic cocatalysts could be divided in two types. The first type of cocatalyst is called photogenerated electron-transfer (usually noble metals, Pt, Pd and $\mathrm{Au}$ ) acting as electron sink and the second type of cocatalyst is called hole-transfer $\left(\mathrm{MoO}_{3}, \mathrm{MnO}_{2}\right.$ and $\mathrm{CoO}$ etc.) [32,33]. Keller et al. [34] fabricated an $\mathrm{Au} / \mathrm{TiO}_{2}-\mathrm{g}-\mathrm{C}_{3} \mathrm{~N}_{4}$ nanocomposite photocatalyst which can achieve to produce hydrogen utilizing ultra low amounts of sacrificial agents under the action of the Au electron cocatalyst. Kang et al. [35] confirmed that $\mathrm{CoO} / \mathrm{g}-\mathrm{C}_{3} \mathrm{~N}_{4}$ heterojunction exhibited higher overall water splitting performance due to the presence of $\mathrm{CoO}$ as a hole cocatalyst. More importantly, Xing et al. [36] have fabricated a novel $\mathrm{MnO}_{x} @ \mathrm{CdS} / \mathrm{CoP}$ catalyst in which $\mathrm{MnO}_{x}$ act as a hole-transfer cocatalyst and CoP act as an electron-transfer cocatalyst, thus accelerating the photocatalytic activity by spatially separating the reduction surface. Yang et al. [37] reported excellent photocatalytic hydrogen evolution by spatial separation of dual cocatalysts ( $\mathrm{Au}$ and $\mathrm{CoP}$ ) to accelerate charge transfer in $3 \mathrm{D}$ ordered microporous g- $\mathrm{C}_{3} \mathrm{~N}_{4}$. From previously reported results, it can be suggested that simultaneous modification of g- $_{3} \mathrm{~N}_{4}$ by dual cocatalysts containing electron-transfer and hole-transfer cocatalysts may accelerate the transportation and separation of photogenerated carriers more efficiently, resulting in higher photocatalytic activity.

Herein, we employed low-temperature phosphating method to fabricate $\mathrm{Co}(\mathrm{II})$-modified P-doped $\mathrm{g}-\mathrm{C}_{3} \mathrm{~N}_{4}$ nanosheets via simultaneous doping of $\mathrm{P}$ atom and coupling of $\mathrm{Co}(\mathrm{II})$ as hole cocatalyst. In the process of photocatalytic hydrogen production, Pt nanoparticles (NPs) as electron cocatalyst could be deposited on the $\mathrm{Co}(\mathrm{II})$-modified P-doped $\mathrm{g}-\mathrm{C}_{3} \mathrm{~N}_{4}$ nanosheets. Furthermore, the synergistic effect of $\mathrm{Pt}$ and $\mathrm{Co}(\mathrm{II})$ cocatalysts for the enhanced photocatalytic performance of P-doped g- $\mathrm{C}_{3} \mathrm{~N}_{4}$ photocatalyst is studied in detail. It has been supposed that the P-doping could optimize the band energy of g- $\mathrm{C}_{3} \mathrm{~N}_{4}$ nanosheets to increase visible-light absorption, while Pt electron-transfer cocatalyst and Co(II) hole-transfer cocatalyst could accelerate the transportation and separation of photoinduced carriers to improve the photocatalytic activity.

\section{Experimental}

\subsection{Synthesis of the Co(II)/PCN composites}

Bulk g- $\mathrm{C}_{3} \mathrm{~N}_{4}$ powders were fabricated using the method of thermal polymerization of urea in accordance to previous literature [38]. The bulk g- $\mathrm{C}_{3} \mathrm{~N}_{4}$ powder $(100 \mathrm{mg})$ was ultrasonically dissolved in $200 \mathrm{~mL}$ deionized $\mathrm{H}_{2} \mathrm{O}$ to obtain g- $\mathrm{C}_{3} \mathrm{~N}_{4}$ nanosheets solution for further use. The schematic illustration for fabrication of Co(II)/PCN composites is shown in Scheme 1. Firstly, a certain amount of $\mathrm{Co}\left(\mathrm{NO}_{3}\right)_{2} \cdot 6 \mathrm{H}_{2} \mathrm{O}$ was added into deionized water $(200 \mathrm{~mL})$ containing $100 \mathrm{mg}$ of $\mathrm{g}-\mathrm{C}_{3} \mathrm{~N}_{4}$ nanosheets and then the mixture solution was stirred for another $2 \mathrm{~h}$ to result in the adsorption equilibrium of cobalt ions. Then the mixture was collected by centrifugation and washed several times with deionized water and ethanol, followed by drying at $60{ }^{\circ} \mathrm{C}$ for $12 \mathrm{~h}$. Subsequently, $50 \mathrm{mg}$ of $\mathrm{Co}(\mathrm{II}) / \mathrm{g}-\mathrm{C}_{3} \mathrm{~N}_{4}$ nanosheets and $500 \mathrm{mg}$ of $\mathrm{NaH}_{2} \mathrm{PO}_{2}$ powder were put into the closed porcelain boat, respectively. Afterwards, the samples were put in a quartz tube of the furnace, maintained at $300{ }^{\circ} \mathrm{C}$ for $2 \mathrm{~h}$ with a heating rate of $2{ }^{\circ} \mathrm{C} / \mathrm{min}$ in an inert atmosphere (Ar flow). After cooling to room temperature, the obtained powders were collected, which were labeled as Co(II)/PCN- $x(x$ $=0.5,2.0,4.0,6.0,8.0)$, where $x$ indicates the weight percentage of $\mathrm{Co}(\mathrm{II})$ in the g- $\mathrm{C}_{3} \mathrm{~N}_{4}$ nanosheets. $\mathrm{P}$ doped $\mathrm{g}-\mathrm{C}_{3} \mathrm{~N}_{4}$ nanosheets were fabricated by the same method except the Co(II) addition and labeled as PCN.

\subsection{Characterization}

The phase, morphology, composition of the as-synthesized materials were characterized by a Ultima IV diffractometer (Rigaku) with $\mathrm{Cu} K_{\alpha}$ radiation $(\lambda=1.5406 \AA$ ), a field-emission transmission electron microscopy (Tecnai G2 F30 S-TWIN, FE-TEM), and a ray photoelectron spectroscopy (XPS) spectra ( G Scientific ESCALAB Mark II spectrometer), respectively. The optical properties and the electron spin resonance experiments

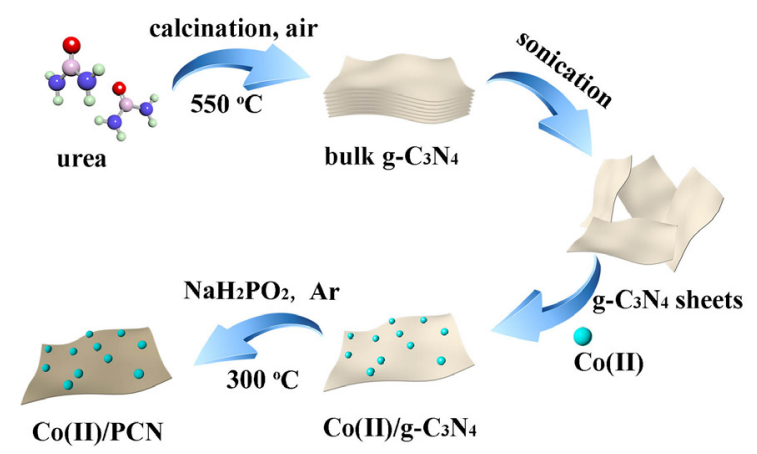

Scheme 1. Schematic illustration of synthesis of Co(II)/PCN composites. 
were characterized by a UV-vis diffuse reflection spectroscopy (DRS, Shimadzu UV2600) and a X-band frequency on a Bruker A300 Spectrometer, respectively. The photocurrent, EIS and Mott-Schottky plots were explored by a CHI 660E electrochemical workstation and the photoluminescence spectra was characterized on a QuantaMaster ${ }^{\mathrm{TM}} 40$.

\subsection{Photocatalytic $\mathrm{H}_{2}$ production measurement}

$50 \mathrm{mg}$ of samples were ultrasonically suspended in a 100 $\mathrm{mL}$ of glass reaction cell containing $80 \mathrm{~mL}$ of $\mathrm{H}_{2} \mathrm{O}$ with $10 \mathrm{vol} \%$ triethanolamine and $400 \mu \mathrm{L}$ of $\mathrm{H}_{2} \mathrm{PtCl}_{6} \cdot 6 \mathrm{H}_{2} \mathrm{O}(10 \mathrm{~g} / \mathrm{L}$, theoretically depositing $3.0 \mathrm{wt} \%$ on the catalyst). Then the cell was kept under a $300 \mathrm{~W}$ Xe lamp with a cutoff filter $(\lambda>420 \mathrm{~nm})$. The amount of $\mathrm{H}_{2}$ was tested by a gas chromatograph equipped with a thermal conductivity detector (TCD) (GC-2014, Shimadzu Co., Japan). The external quantum efficiencies (EQE) of optimized Co(II)/PCN were calculated via the following equation:

$\mathrm{EQE}=\frac{2 \times \text { the amount of hydrogen molecules evolved in unit time }}{\text { number of incident photons in unit time }} \times 100 \%$

\section{Results and discussion}

The crystal structures and phase compositions of the as-prepared g- $\mathrm{C}_{3} \mathrm{~N}_{4}$ nanosheets and $\mathrm{Co}(\mathrm{II}) / \mathrm{PCN}-2$ were studied by XRD as shown in Fig. 1(a). Two characteristic peaks are existed in the XRD patterns of both $\mathrm{g}-\mathrm{C}_{3} \mathrm{~N}_{4}$ nanosheets and $\mathrm{Co}(\mathrm{II}) / \mathrm{PCN}-2$. The (100) peak at $13.1^{\circ}$ and $(002)$ peak at $27.5^{\circ}$ are assigned to the in-plane structural packing motif of tris-triazine units and the interlayer stacking of aromatic seg- ments [39]. The XRD pattern of the Co(II)/PCN is similar to that of $\mathrm{g}-\mathrm{C}_{3} \mathrm{~N}_{4}$ nanosheets. The presence of $\mathrm{Co}(\mathrm{II})$ and confirmation of $\mathrm{P}$ doping are verified by XPS and TEM-EDX. The XPS survey spectra of $\mathrm{g}-\mathrm{C}_{3} \mathrm{~N}_{4}$ nanosheets and $\mathrm{Co}(\mathrm{II}) / \mathrm{PCN}-2$ are shown in Fig. 1(b). As expected, two peaks of Co and $\mathrm{P}$ appear in the spectrum of $\mathrm{Co}(\mathrm{II}) / \mathrm{PCN}-2$ except for the peaks of $\mathrm{C}$ and $\mathrm{N}$ elements in both $\mathrm{g}-\mathrm{C}_{3} \mathrm{~N}_{4}$ nanosheets and $\mathrm{Co}(\mathrm{II}) / \mathrm{PCN}-2$. Figs. 1(c)-(f) show high-resolution XPS spectra of individual elements. The dominant peak in the high-resolution $\mathrm{C} 1 \mathrm{~s}$ spectra located at $284.8 \mathrm{eV}$ is assigned to the $\mathrm{C}-\mathrm{C}$ species of $\mathrm{g}-\mathrm{C}_{3} \mathrm{~N}_{4}$ nanosheets, while the peak at $288.0 \mathrm{eV}$ is originated from the $s p^{2}$-hybridized $\mathrm{C}$ in $\mathrm{N}=\mathrm{C}-\mathrm{N}[40,41]$. The spectrum of $\mathrm{N} 1 s$ signal is deconvoluted into four peaks centered at 398.7, 399.6, 401.0, and $404.5 \mathrm{eV}$, which are attributed to the triazine rings $(\mathrm{C}=\mathrm{N}-\mathrm{C})$ of $\mathrm{g}-\mathrm{C}_{3} \mathrm{~N}_{4}, \mathrm{~N}-(\mathrm{C})_{3}$ groups, $\mathrm{C}-\mathrm{N}-\mathrm{H}$ and $\mathrm{C}=\mathrm{N}$ conjugated structures, respectively [42]. Obviously, the binding energy of Co(II)/PCN displayed in the high-resolution C and N XPS spectra shows a significant positive shift, revealing the reduction of electron density in $\mathrm{g}^{-} \mathrm{C}_{3} \mathrm{~N}_{4}$ due to the incorporation of dopant (P) and the Co(II) deposition. The high-resolution Co $2 p$ XPS spectrum of Co(II)/PCN-2 exhibits two strong peak located at 780.3 and $795.7 \mathrm{eV}$, respectively, which are ascribed to Co $2 p_{1 / 2}$ and Co $2 p_{3 / 2}$, respectively, manifesting the existence of the Co(II) in the heterojunction [43]. Considering a low-temperature hydrolysis process in this study, the Co(II) cocatalyst may be in the amorphous $\mathrm{CoOOH}$-like structure, similar to the reported phenomenon of the other transition metal (such as Fe elements) [44]. The high-resolution P $2 p$ XPS spectrum exhibits a strong peak at $133.4 \mathrm{eV}$ attributing to $\mathrm{P}-\mathrm{N}$ coordination, revealing that $\mathrm{P}$ atoms may substitute the $\mathrm{C}$ atom
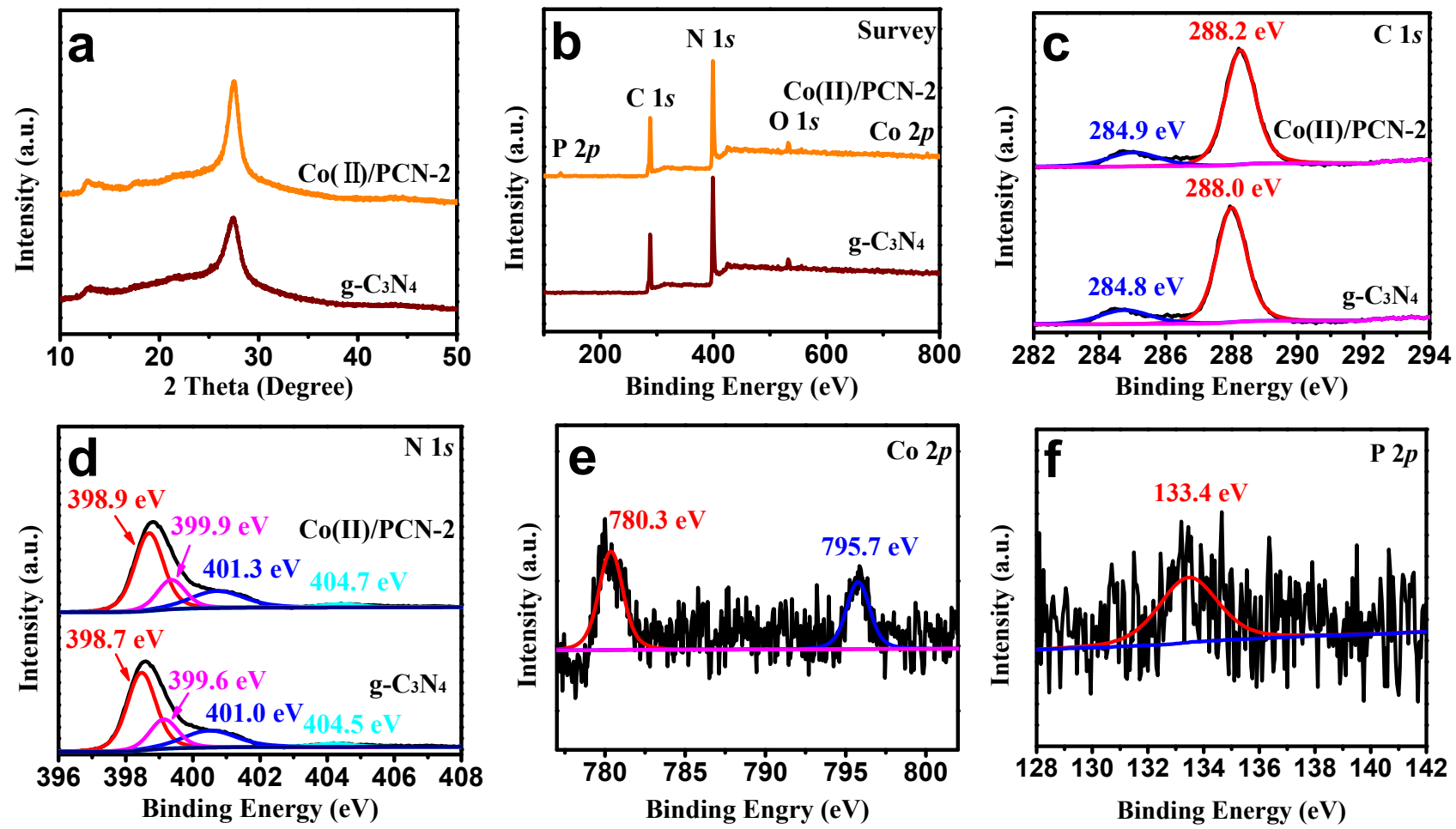

Fig. 1. XRD patterns (a), XPS survey spectra (b), C $1 s(\mathrm{c}), \mathrm{N} 1 s(\mathrm{~d})$, Co $2 p(\mathrm{e})$ and $\mathrm{P} 2 p$ (f) high-resolution spectra of g- $\mathrm{C}_{3} \mathrm{~N}_{4}$ nanosheets and Co(II)/PCN-2 composite. 

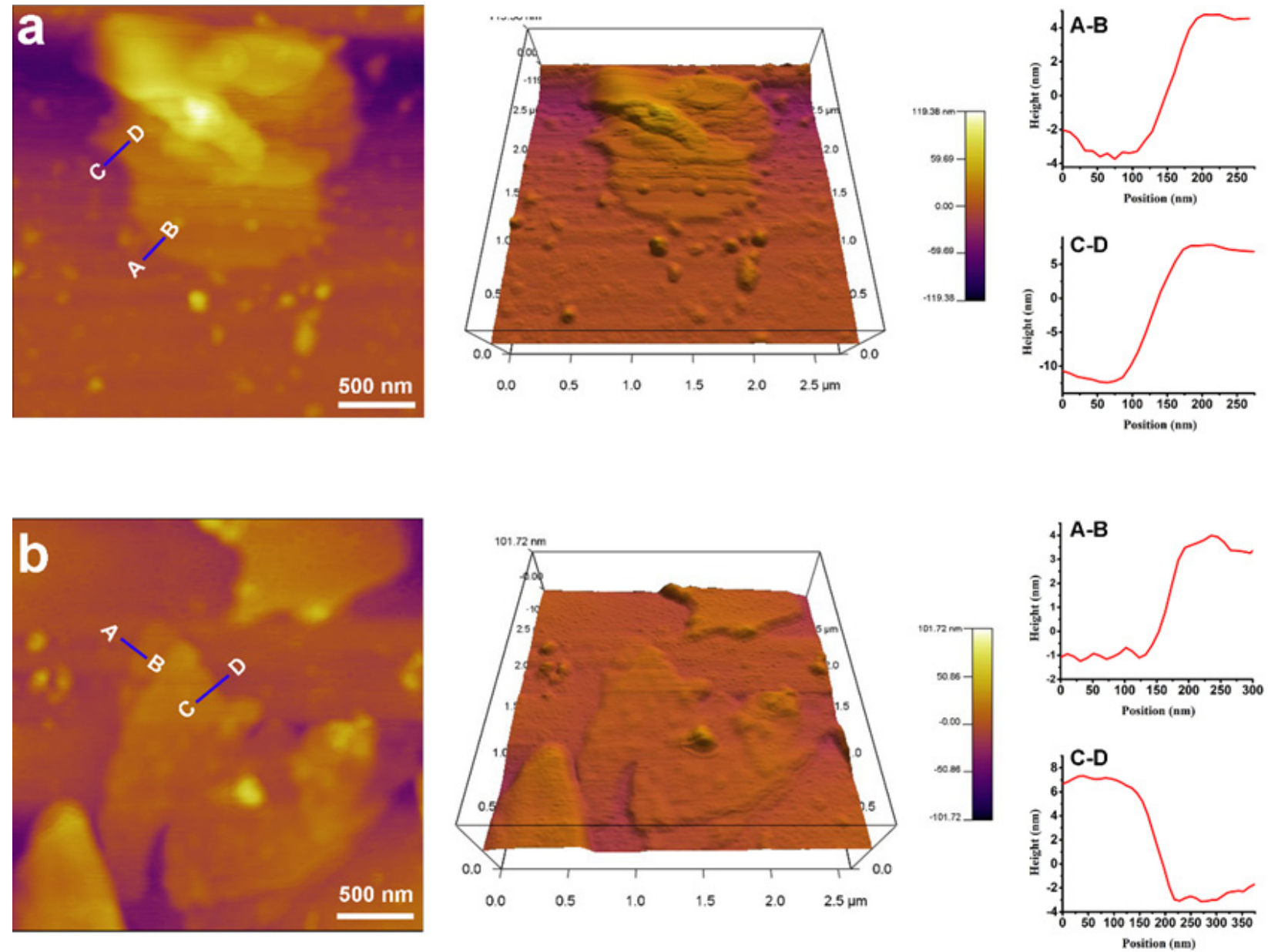

Fig. 2. AFM images of (a) bulk g- $\mathrm{C}_{3} \mathrm{~N}_{4}$ and (b) g- $\mathrm{C}_{3} \mathrm{~N}_{4}$ nanosheets.

in the triazine rings of the $\mathrm{g}-\mathrm{C}_{3} \mathrm{~N}_{4}$ and thus form $\mathrm{P}-\mathrm{N}$ bonds [45]. The results of the XRD and XPS confirm the successful preparation of coupling of $\mathrm{Co}(\mathrm{II})$ with P-doped g- $\mathrm{C}_{3} \mathrm{~N}_{4}$.

The atomic force microscope (AFM) was employed to investigate the thickness of as-prepared samples. Fig. 2 indicates that bulk g- $\mathrm{C}_{3} \mathrm{~N}_{4}$ has a thickness of $15-20 \mathrm{~nm}$, while the thickness of g- $\mathrm{C}_{3} \mathrm{~N}_{4}$ nanosheets ranges from 5 to $10 \mathrm{~nm}$, manifesting that the bulk $\mathrm{g}-\mathrm{C}_{3} \mathrm{~N}_{4}$ can exfoliate into few-layered structures after ultrasonic exfoliation process. Such ultrathin $\mathrm{g}-\mathrm{C}_{3} \mathrm{~N}_{4}$ nanosheets were utilized to further realize $\mathrm{P}$ doping and heterojunction construction.

Furthermore, TEM and STEM-EDX elemental mapping were conducted to observe the morphologies of pure $\mathrm{g}-\mathrm{C}_{3} \mathrm{~N}_{4}$ nanosheets and $\mathrm{Co}(\mathrm{II}) / \mathrm{PCN}-2$. As observed in Fig. 3(a), g- $\mathrm{C}_{3} \mathrm{~N}_{4}$ nanosheets have small thin flat irregular two-dimensional shape. TEM image of Co(II)/PCN-2 (Fig. 3(b)) shows that phosphorus doping and Co(II) loading did not affect the morphology of $\mathrm{g}-\mathrm{C}_{3} \mathrm{~N}_{4}$ nanosheets. STEM-EDX elemental mappings (Fig. 3(c)) confirm the existence and uniform distributions of $\mathrm{C}$, $\mathrm{N}$, Co, P elements. Based on XRD, XPS, TEM and EDX analysis, it can be concluded that $P$ atoms are doped into $g-\mathrm{C}_{3} \mathrm{~N}_{4}$ nanosheets and Co(II) exists on the surface of the P-doped g- $\mathrm{C}_{3} \mathrm{~N}_{4}$ nanosheets.

The visible light photocatalytic $\mathrm{H}_{2}$ production activity over pure g- $\mathrm{C}_{3} \mathrm{~N}_{4}$ nanosheets, PCN and $\mathrm{Co}(\mathrm{II}) / \mathrm{PCN}$ were evaluated. As shown in Figs. 4(a) and (b), pure g- $\mathrm{C}_{3} \mathrm{~N}_{4}$ nanosheets have relatively low hydrogen production rate $\left(89.2 \mu \mathrm{mol} \cdot \mathrm{g}^{-1} \cdot \mathrm{h}^{-1}\right)$. However, the hydrogen production of PCN $\left(155.2 \mu \mathrm{mol} \cdot \mathrm{g}^{-1} \cdot \mathrm{h}^{-1}\right)$ exhibits 1.7 folds higher than that of pristine $\mathrm{g}-\mathrm{C}_{3} \mathrm{~N}_{4}$ nanosheets. Generally, $\mathrm{P}$ doping into $\mathrm{g}-\mathrm{C}_{3} \mathrm{~N}_{4}$ nanosheets can introduce an impurity level which can accelerate the separation of photogenerated carriers and result in the improvement of the photocatalytic activity. Also Co(II)/PCN with different mod-

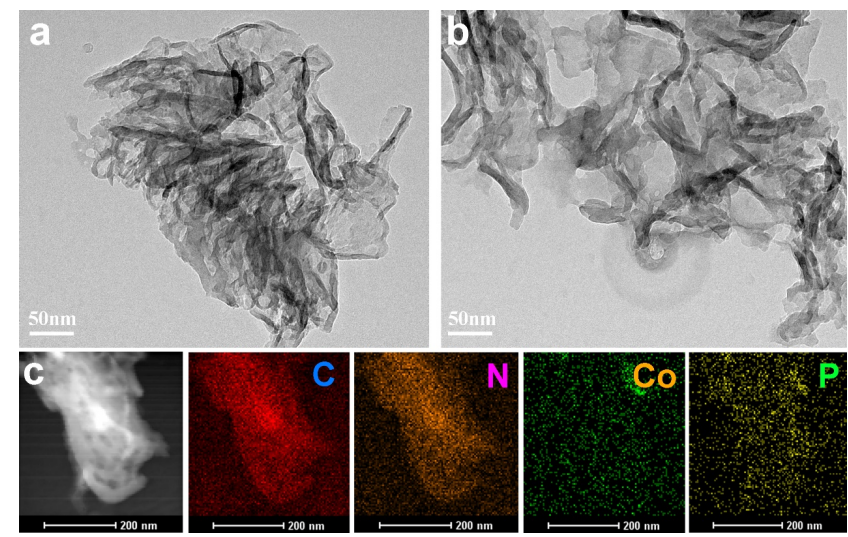

Fig. 3. (a) TEM image of $g-\mathrm{C}_{3} \mathrm{~N}_{4}$ nanosheets; TEM image (b) and STEM-EDX elemental mapping (c) for Co(II)/PCN-2. 

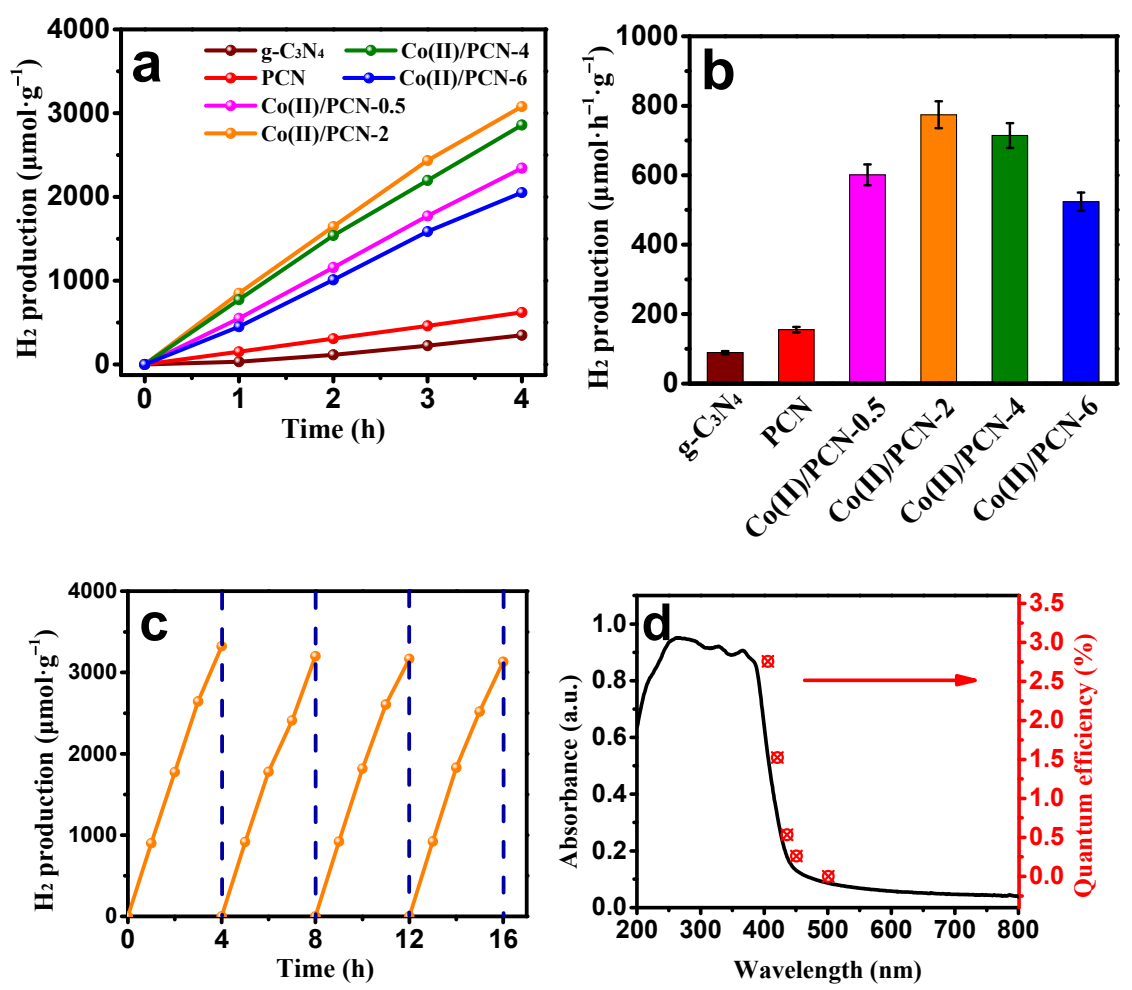

Fig. 4. Photocatalytic $\mathrm{H}_{2}$-production activity (a) and $\mathrm{H}_{2}$-production rate (b) of g- $\mathrm{C}_{3} \mathrm{~N}_{4}$ nanosheets and $\mathrm{Co}(\mathrm{II}) / \mathrm{PCN}$ with different contents of Co(II); Recycling of the $\mathrm{H}_{2}$ production tests (c) and external quantum efficiency (d) of Co(II)/PCN-2.

ified amounts of Co(II) shows the improved photocatalytic properties in comparison to pure g- $\mathrm{C}_{3} \mathrm{~N}_{4}$ nanosheets. Upon increasing the loading amount of Co(II) from $0.5 \mathrm{wt} \%$ to $2 \mathrm{wt} \%$, the Co(II)/PCN samples show continuously increasing photocatalytic activity. However, When the loading amount of Co(II) was further increased from $2.0 \mathrm{wt} \%$ to $6.0 \mathrm{wt} \%$, the photocatalytic $\mathrm{H}_{2}$ activity decrease, which can be ascribed to the shielding effect of $\mathrm{Co}(\mathrm{II})$. The $\mathrm{Co}(\mathrm{II}) / \mathrm{PCN}-2$ sample shows the highest photocatalytic performance $\left(774 \mu \mathrm{mol} \cdot \mathrm{g}^{-1} \cdot \mathrm{h}^{-1}\right)$, exhibiting 8.6 folds higher than that of pure g- $\mathrm{C}_{3} \mathrm{~N}_{4}$ nanosheets. This indicates that the optimized $\mathrm{Co}(\mathrm{II})$ loading can effectively enhance the water-reduced $\mathrm{H}_{2}$-production activity.

The cyclic stability of the $\mathrm{Co}(\mathrm{II}) / \mathrm{PCN}-2$ sample was also studied. The composite exhibits almost stable $\mathrm{H}_{2}$-evolution rate with a little decline after four cycles, revealing that Co(II)/PCN-2 sample exhibits reliable stability for the photocatalytic $\mathrm{H}_{2}$-evolution, as shown in Fig. 4(c). The external quantum efficiencies (EQE) at different wavelengths of $\mathrm{Co}(\mathrm{II}) / \mathrm{PCN}-2$ were measured, and the EQE at $\lambda=402 \mathrm{~nm}$ is determined to be $2.76 \%$ (Fig. 4 (d)).

Strong light-harvest capability, high separating efficiency of photoinduced carriers, as well as large surface reactions efficiency are important determining factors for excellent photocatalytic $\mathrm{H}_{2}$-evolution property. The UV-vis DRS of $\mathrm{g}-\mathrm{C}_{3} \mathrm{~N}_{4}$ nanosheets and $\mathrm{Co}(\mathrm{II}) / \mathrm{PCN}-2$ composite shown in Fig. 5(a) demonstrated that an enhancement of light absorption over g- $\mathrm{C}_{3} \mathrm{~N}_{4}$ is achieved after $\mathrm{P}$ doping and $\mathrm{Co}(\mathrm{II})$ decoration, and thus the $\mathrm{Co}(\mathrm{II}) / \mathrm{PCN}-2$ has the better visible light absorption ability than pure $\mathrm{g}-\mathrm{C}_{3} \mathrm{~N}_{4}$ nanosheets. Kubelk-Munk function is employed to calculate the bandgap of g- $\mathrm{C}_{3} \mathrm{~N}_{4}$, which is determined to be $2.66 \mathrm{eV}$ (Fig. 5(b)). As shown in Figs. 5(c)-(d), both g- $\mathrm{C}_{3} \mathrm{~N}_{4}$ nanosheets and $\mathrm{Co}(\mathrm{II}) / \mathrm{PCN}-2$ show positive slopes at different frequencies, indicating the classic n-type nature of semiconductor whether or not modified. According to the Mott-Schottky plots shown in Fig. 5(c) and the equation of the $E_{\mathrm{fb}}=E_{\mathrm{Ag} / \mathrm{AgCl}}+0.059 \times \mathrm{pH}+E_{\mathrm{Ag} / \mathrm{AgCl}}^{*}[46]$, the hydrogen electrode potentials (NHE) of g- $\mathrm{C}_{3} \mathrm{~N}_{4}$ nanosheets and $\mathrm{Co}(\mathrm{II}) / \mathrm{PCN}-2$ are determined as -0.67 and $-0.53 \mathrm{~V}$ versus NHE, which are consistent with reported literatures [47]. Obviously, Co(II)/PCN-2 shows more positive flat-band potential than g- $\mathrm{C}_{3} \mathrm{~N}_{4}$ nanosheets, which might be caused by the lower overpotential as well as splendid electronic conductivity of Co(II) $[48,49]$.

The photocurrent-time curves $(i-t)$ of $\mathrm{Co}(\mathrm{II}) / \mathrm{PCN}-2$ working electrode were measured to examine the separation efficiency of photo-excited carriers. Apparently, the Co(II)/PCN-2 exhibits stronger photocurrent density than that of the $\mathrm{g}-\mathrm{C}_{3} \mathrm{~N}_{4}$ nanosheets (Fig. 6(a)), implying $\mathrm{Co}(\mathrm{II}) / \mathrm{PCN}-2$ exhibits faster separation of photo-generated electron-holes [50,51]. Also, $\mathrm{Co}(\mathrm{II}) / \mathrm{PCN}-2$ possesses a smaller arc than that of $\mathrm{g}-\mathrm{C}_{3} \mathrm{~N}_{4}$ nanosheets (Fig. 6(b)), which is the indication of rapid transportation rate of photogenerated electrons occurs due to P-doping and Co(II) decorated nanosheets surface [52]. The photoluminescence (PL) measurement had also been applied to study the separation of the photo-excited carriers. Fig. 6(c) shows the PL emission spectra of $\mathrm{Co}(\mathrm{II}) / \mathrm{PCN}-2$ and $\mathrm{g}-\mathrm{C}_{3} \mathrm{~N}_{4}$ nanosheets both located at $\sim 450 \mathrm{~nm}$. The intensity of PL emission peak for $\mathrm{Co}(\mathrm{II}) / \mathrm{PCN}-2$ is lower than that of $\mathrm{g}-\mathrm{C}_{3} \mathrm{~N}_{4}$ 

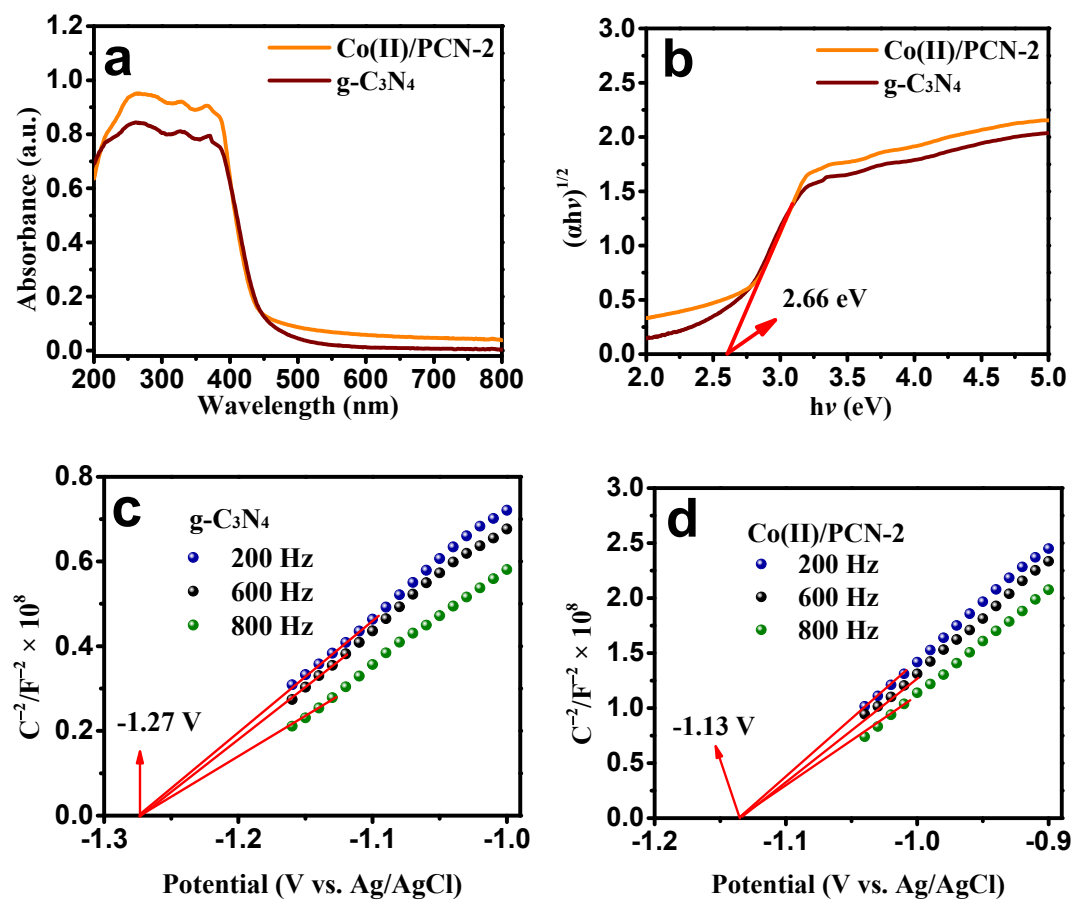

Fig. 5. UV-vis DRS (a) and estimated band energy spectra (b) of g- $\mathrm{C}_{3} \mathrm{~N}_{4}$ nanosheets and Co(II)/PCN-2; Mott-Schottky plots of g- $\mathrm{C}_{3} \mathrm{~N}_{4}$ nanosheets (c) and $\mathrm{Co}(\mathrm{II}) / \mathrm{PCN}-2$ (d) at different frequencies in $0.5 \mathrm{M} \mathrm{Na}_{2} \mathrm{SO}_{4}$ solution.
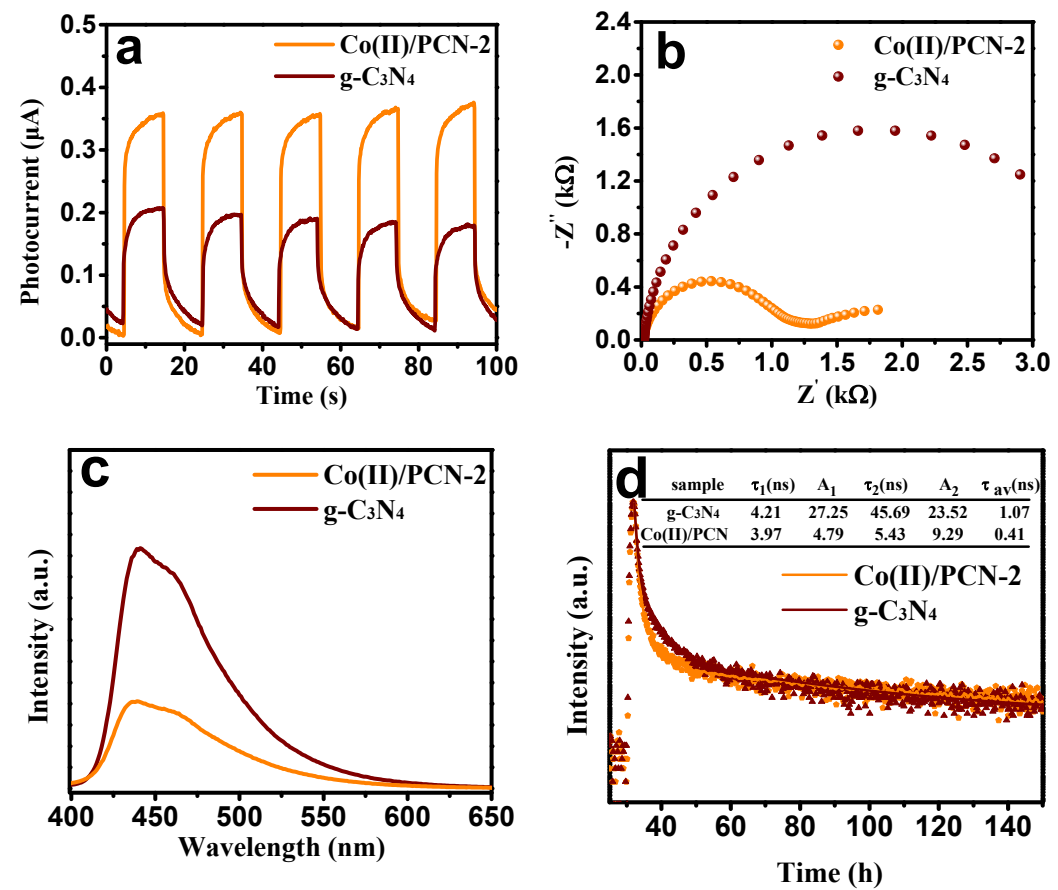

Fig. 6. Transient photocurrent responses (a), Electrochemical impedance spectroscopy (EIS) Nyquist plots (b), Photoluminescence spectra (c), and Time-resolved photoluminescence (d) of pure g- $\mathrm{C}_{3} \mathrm{~N}_{4}$ nanosheets and $\mathrm{Co}(\mathrm{II}) / \mathrm{PCN}-2$.

nanosheets, indicating faster charge separation ability over the $\mathrm{Co}(\mathrm{II}) / \mathrm{PCN}-2$ [53]. Time-resolved photoluminescence measurements were employed to explore the lifetime of photogenerated carriers. The PL intensities, corresponding pre-exponential factors and mean lifetimes of $\mathrm{g}-\mathrm{C}_{3} \mathrm{~N}_{4}$ and Co(II)/PCN-2 are shown in Fig. 6(d), a smaller lifetime (0.41 ns) is observed for the $\mathrm{Co}(\mathrm{II}) / \mathrm{PCN}-2$ compared with the $\mathrm{g}-\mathrm{C}_{3} \mathrm{~N}_{4}$ nanosheets (1.07 ns), revealing that $\mathrm{Co}(\mathrm{II}) / \mathrm{PCN}-2$ has the faster transportation of photogenerated electrons in case of Co(II)/PCN-2 [54]. The results of PL measurement are well consistent with the results of photocurrent and EIS measurements, The improved separation efficiency of the photo-generated carriers of $\mathrm{Co}(\mathrm{II}) / \mathrm{PCN}$ composite can enhance the photocatalytic activity. 

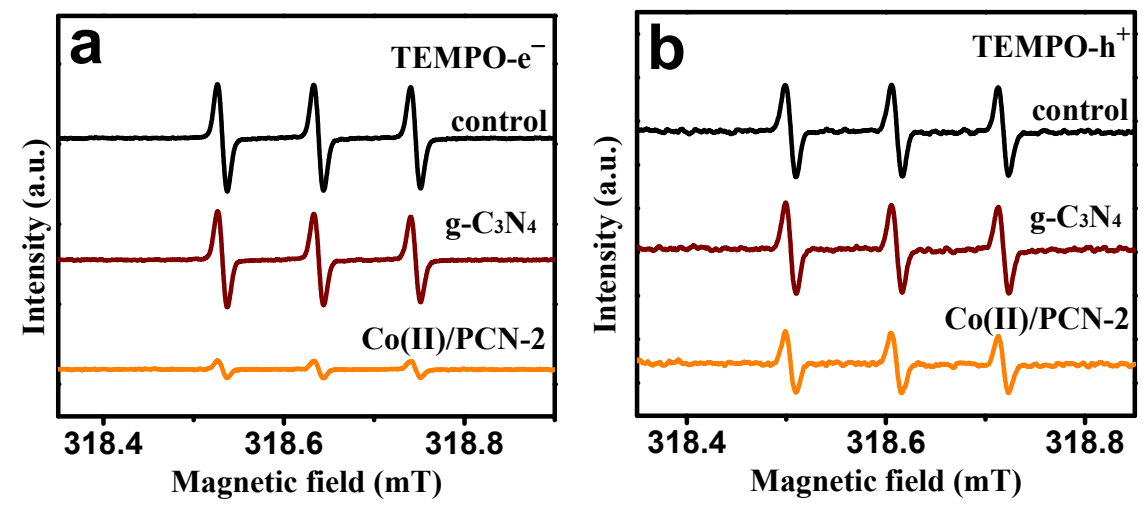

Fig. 7. TEMPO- $\mathrm{e}^{-}$(a) and TEMPO- $\mathrm{h}^{+}$(b) of pure $\mathrm{g}-\mathrm{C}_{3} \mathrm{~N}_{4}$ and $\mathrm{Co}$ (II)/PCN-2 sample under visible light irradiation.

The generation of the $\mathrm{e}^{-}$and $\mathrm{h}^{+}$of $\mathrm{g}-\mathrm{C}_{3} \mathrm{~N}_{4}$ and $\mathrm{Co}(\mathrm{II}) / \mathrm{PCN}-2$ were characterized by the electron spin resonance (ESR). Usually, reduced ESR signal intensity indicates faster transfer rate of electrons from semiconductor to the spin label [55,56]. As shown in Figs. 7(a) and (b), whatever for the TEMPO- $\mathrm{e}^{-}$and TEMPO- $\mathrm{h}^{+}$, both of the signal intensities of the $\mathrm{g}-\mathrm{C}_{3} \mathrm{~N}_{4}$ and $\mathrm{Co}(\mathrm{II}) / \mathrm{PCN}-2$ aqueous solution decreased within $5 \mathrm{~min}$, however, more attenuation could be observed in the Co(II)/PCN-2. The above results demonstrate that, under light irradiation, $\mathrm{Co}(\mathrm{II}) / \mathrm{PCN}-2$ composite excites more active electrons and holes compared to g- $\mathrm{C}_{3} \mathrm{~N}_{4}$ nanosheets, which also means $\mathrm{P}$ doping and $\mathrm{Co}(\mathrm{II})$ decorated nanosheets surface could effectively improve the reactivity of the photoinduced $\mathrm{e}^{-}$and $\mathrm{h}^{+}$. It is evident from the above results that $\mathrm{Co}(\mathrm{II}) / \mathrm{PCN}-2$ sample demonstrates better separation of the photo-generated $\mathrm{e}^{-}$and $\mathrm{h}^{+}$.

The XRD patterns of the Co(II)/PCN-2 sample before and after the photocatalytic reaction are shown in Fig. 8(a), There is no obvious difference between $\mathrm{Co}(\mathrm{II}) / \mathrm{PCN}-2$ and $\mathrm{Pt} / \mathrm{Co}(\mathrm{II}) / \mathrm{PCN}$ due to loading of a small amount of $\mathrm{Pt}$ on the Co(II)/PCN (only 3.0 wt $\%$ relative to $\mathrm{Co}(\mathrm{II}) / \mathrm{PCN}$ ). The TEM image of the $\mathrm{Co}(\mathrm{II}) / \mathrm{PCN}-2$ sample after the photocatalytic reaction is shown in Fig. 8(b), Some nanoparticles of diameter $5 \mathrm{~nm}$ were found on the Co(II)/PCN-2 sample, which were not present previously. Furthermore, interplanar spacing of $0.23 \mathrm{~nm}$ corresponding to (111) facets of Pt was determined in HRTEM image [57]. It is assumed that under the irradiation of the Xe lamp, the $\mathrm{PtCl}_{6}{ }^{2-}$ is reduced to $\mathrm{Pt}$ by the incoming the electron from the conduction band of P-doped $\mathrm{g}-\mathrm{C}_{3} \mathrm{~N}_{4}$ nanosheets and acting as electron-transfer cocatalyst to promote half-reaction
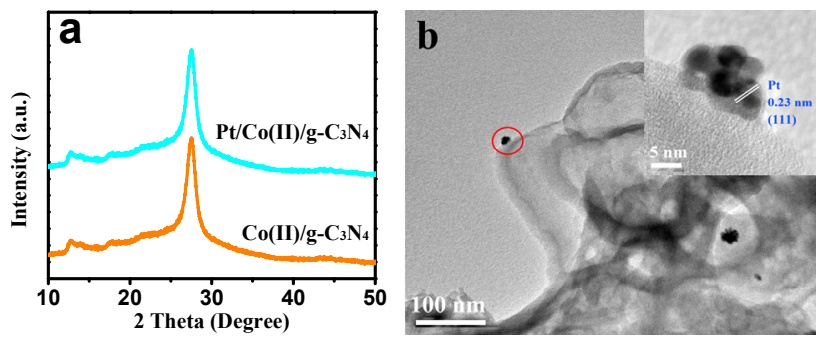

Fig. 8. XRD patterns (a) and TEM (HRTEM inset) images (b) of Co(II)/PCN-2 composite loaded with $3.0 \mathrm{wt} \% \mathrm{Pt}$. of hydrogen production [58].

The proposed mechanism for photocatalytic hydrogen production over Co(II)/PCN in the light of the above discussion is shown in Fig. 9. The g- $\mathrm{C}_{3} \mathrm{~N}_{4}$ nanosheets could be excited to generate $\mathrm{e}^{-}$and $\mathrm{h}^{+}$under light irradiation. The dopant " $\mathrm{P}$ " in the g- $\mathrm{C}_{3} \mathrm{~N}_{4}$ nanosheets could provide new channels to mediate electron migration and restrain the recombination of electrons and holes. In case of $\mathrm{Co}$ (II) decorated P-doped $\mathrm{g}^{-\mathrm{C}_{3} \mathrm{~N}_{4}}$ nanosheets, $\mathrm{Co}(\mathrm{II})$ captures photogenerated hole to form Co(III), and the new-formative Co(III) will be reduced to Co(II) by oxidizing sacrificial agent (TEOA) due to the high oxidative capacity of Co(III) [59]. Herein, the Co(II) plays role of $\mathrm{h}^{+}$-transfer cocatalyst to capture $\mathrm{h}^{+}$in present photocatalytic system. Furthermore, the photogenerated- $\mathrm{e}^{-}$will first reduce $\mathrm{PtCl}_{6}{ }^{2-}$ to $\mathrm{Pt}$ according photoreduction deposition. After the formation of Pt, it can act as the electron-transfer cocatalysts to take control of the photogenerated-e- in order to provide the active sites for hydrogen production. Therefore, with the synergistic effect of Co(II) as a hole cocatalyst and Pt as electron cocatalyst, electrons and holes demonstrated the directional shunting, which could further accelerate the migration of photogenerated electrons to platinum in order to join the photocatalytic reduction process for hydrogen evolution. It can be concluded that the transportation and separation of photogenerated carriers were accelerated to the greatest extent over the

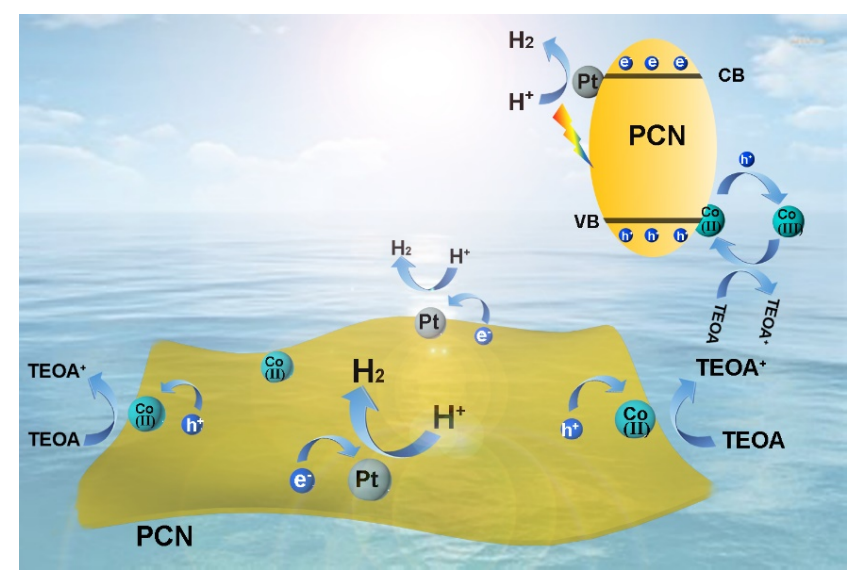

Fig. 9. Mechanism for photocatalytic hydrogen generation over Pt/Co(II)/PCN system. 
Pt/Co(II)/PCN photocatalyst. The enhancement of photocatalytic performance of $\mathrm{Co}(\mathrm{II}) / \mathrm{PCN}-2$ can be ascribed to the synergistic effects of Co(II), Pt deposition and P doping.

\section{Conclusions}

In summary, we employed low-temperature phosphating method to fabricate Co(II)-modified P-doped g- $\mathrm{C}_{3} \mathrm{~N}_{4}$ nanosheets, which simultaneously realized the P-doping and Co (II) as hole cocatalyst co-modification, and Pt is deposited as electron cocatalyst for the photocatalytic $\mathrm{H}_{2}$ generation. The results of XRD, XPS, TEM and STEM confirmed the successful preparation of the $\mathrm{Co}(\mathrm{II}) / \mathrm{PCN}$ samples, in which $\mathrm{P}$ element is doped into $\mathrm{g}-\mathrm{C}_{3} \mathrm{~N}_{4}$ nanosheets and $\mathrm{Co}(\mathrm{II})$ is decorated on the surface of P-doped g- $\mathrm{C}_{3} \mathrm{~N}_{4}$ nanosheets successfully. The optimized Co(II)/PCN sample exhibited the highest photocatalytic hydrogen evolution $\left(774 \mu \mathrm{mol} \cdot \mathrm{g}^{-1} \cdot \mathrm{h}^{-1}\right)$ by using $\mathrm{Pt}$ as electron transfer cocatalyst, which is $\sim 8.6$ fold higher than pristine g- $\mathrm{C}_{3} \mathrm{~N}_{4}$ nanosheets $\left(89.2 \mu \mathrm{mol} \cdot \mathrm{g}^{-1} \cdot \mathrm{h}^{-1}\right)$. The enhancement in photocatalytic activity is resulted from the faster separation of photogenerated $\mathrm{e}^{-}$and $\mathrm{h}^{+}$caused by the synergistic effect of Co(II) (hole transfer cocatalyst), Pt (electron transfer cocatalyst) and $\mathrm{P}$ doping (modulate the electronic structure of $\mathrm{g}-\mathrm{C}_{3} \mathrm{~N}_{4}$ ) of the Co(II)/PCN heterojunction. This work offers a novel insight into the designing of excellent photocatalysts consisting of both hole-transfer and electron-transfer cocatalysts for energy conversion application.

\section{References}

[1] P. F. Wang, T. F. Wu, C. Wang, J. Hou, J. Qian, Y. H. Ao, ACS Sustain. Chem. Eng., 2017, 5, 7670-7677.

[2] A. Y. Meng, B. C. Zhu, B. Zhong, L. Y. Zhang, B. Cheng, Appl. Surf. Sci., 2017, 422, 518-527.

[3] F. Y. Xu, L. Y. Zhang, B. Cheng, J. G. Yu, ACS Sustain. Chem. Eng., 2018, 6, 12291-12298.

[4] J. X. Low, B. Z. Dai, T. Tong, C. J. Jiang, J. G. Yu, Adv. Mater., 2019, 31,
1802981.

[5] B. C. Qiu, Q. H. Zhu, M. Y. Xing, J. L. Zhang, Chem. Commun., 2017, $53,897-900$

[6] K. Yang, X. X. Li, C. L. Yu, D. B. Zeng, F. Y. Chen, K. L. Zhang, W. Y. Huang, H. B. Ji, Chin. J. Catal., 2019, 40, 796-818.

[7] K. Z. Qi, B. Cheng, J. G. Yu, W. K. Ho, Chin. J. Catal., 2017, 38, 1936-1955.

[8] J. Shen, R. Wang, Q. Q. Liu, X. F. Yang, H. Tang, J. Yang, Chin. J. Catal., 2019, 40, 380-389.

[9] X. Li, S. W. Liu, K. Fan, Z. Q. Liu, B. Song, J. G. Yu, Adv. Energy Mater., 2018, 8, 1800101

[10] R. Chen, P. F. Wang, J. Chen, C. Wang, Y. H. Ao, Appl. Surf. Sci, 2019, $473,11-19$.

[11] X. H. Wu, X. F. Wang, F. Z. Wang, H. G. Yu, Appl. Catal. B, 2019, 247, 70-77.

[12] X. C. Wang, K. Maeda, A. Thomas, K. Takanabe, G. Xin, J. M. Carlsson, K. Domen, M. Antonietti, Nat. Mater., 2009, 8, 76-80.

[13] C. Y. Liu, H. W. Huang, L. Q. Ye, S. X. Yu, N. Tian, X. Du, T. R. Zhang, Y. H. Zhang, Nano Energy, 2017, 41, 738-748.

[14] C. L. Yu, H. B. He, W. Q. Zhou, Z. Liu, L. F. Wei, Sep. Purif. Technol, 2019, 217, 137-146.

[15] J. Q. Wen, J. Xie, X. B. Chen, X. Li, Appl. Surf. Sci., 2017, 391, 72-123.

[16] J. W. Fu, J. G. Yu, C. J. Jiang, B. Cheng, Adv. Energy Mater., 2018, 8, 1701503.

[17] T. F. Wu, P. F. Wang, J. Qian, Y. H. Ao, C. Wang, J. Hou, Dalton Trans., 2017, 46, 13793-13801.

[18] N. Tian, Y. H. Zhang, X. W. Li, K. Xiao, X. Du, F. Dong, G. I. N. Waterhouse, T. R. Zhang, H. W. Huang, Nano Energy, 2017, 38, 72-81.

[19] F. Chen, H. Yang, W. Luo, P. Wang, H. G. Yu, Chin. J. Catal., 2017, 38, 1990-1998.

[20] P. F. Xia, B. C. Zhu, J. G. Yu, S. W. Cao, M. Jaroniec, J. Mater. Chem. A, 2017, 5, 3230-3238.

[21] Q. Q. Liu, J. Y. Shen, X. H. Yu, X. F. Yang, W. Liu, J. Yang, H. Tang, H. Xu, H. M. Li, Y. Y. Li, J. S. Xu, Appl. Catal. B, 2019, 248, 84-94.

[22] Y. J. Ren, D. Q. Zeng, W. J. Ong, Chin. J. Catal., 2019, 40, 289-319.

[23] S. X. Hua, D. Qu, L. An, G. C. Xi, G. Chen, F. Li, Z. J. Zhou, Z. C. Sun, Chin. J. Catal., 2017, 38, 1028-1037.

[24] X. Y. Feng, P. F. Wang, J. Hou, J. Qian, C. Wang, Y. H. Ao, Chem. Eng.

\section{Graphical Abstract}

Chin. J. Catal., 2020, 41: 72-81 doi: S1872-2067(19)63430-3

\section{Synergistic effect of Co(II)-hole and Pt-electron cocatalysts for enhanced photocatalytic hydrogen evolution performance of P-doped g- $\mathrm{C}_{3} \mathrm{~N}_{4}$}

Kouhua Sun, Jun Shen, Qinqin Liu, Hua Tang *, Mingyi Zhang, Syed Zulfiqar, Chunsheng Lei*

Changzhou University; Suzhou Vocational Health College; Jiangsu University; Harbin Normal University

Co(II) decorated P doped g- $\mathrm{C}_{3} \mathrm{~N}_{4}$ with optimized electronic structure shows excellent photocatalytic $\mathrm{H}_{2}$-production, which is ascribed the directional shunting of electron-hole pairs via Co(II) and Pt.

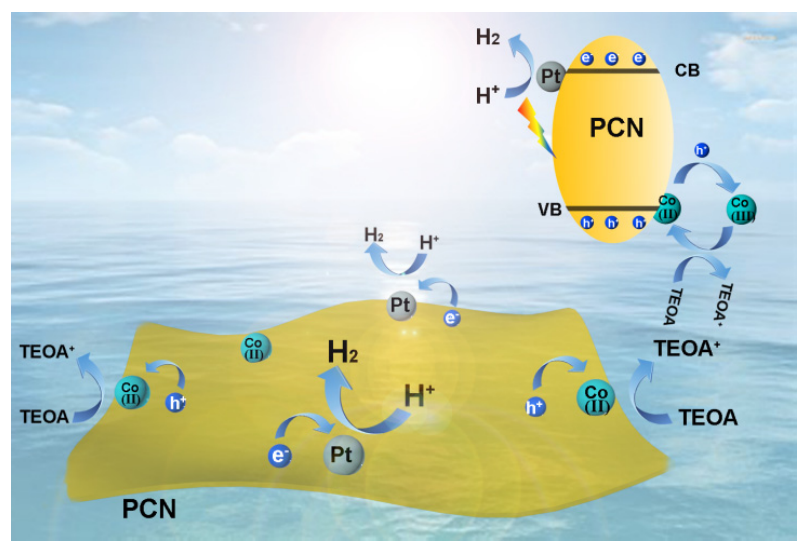


J., 2018, 352, 947-956.

[25] X. H. Li, J. Zhang, F. Zhou, H. L. Zhang, J. Bai, Y. J. Wang, H. Y. Wang, Chin. J. Catal., 2018, 39, 1090-1098.

[26] M. Wu, J. Zhang, B. B. He, H. W. Wang, R. Wang, Y. S. Gong, Appl. Catal. B, 2019, 241, 159-166.

[27] S. E. Guo, Z. P. Deng, M. X. Li, B. J. Jiang, C. G. Tian, Q. J. Pan, H. G. Fu, Angew. Chem. Int. Ed., 2016, 55, 1830-1834.

[28] J. R. Ran, T. Y. Ma, G. P. Gao, X. W. Du, S. Z. Qiao, Energy Environ. Sci, 2015, 8, 3708-3717.

[29] M. Bellardita, E. I. Garcia-Lopez, G. Marci, I. Krivtsov, J. R. Garcia, L. Palmisano, Appl. Catal. B, 2018, 220, 222-233.

[30] F. Chen, H. Yang, X. F. Wang, H. G. Yu, Chin. J. Catal., 2017, 38, 296-304.

[31] N. Li, J. Zhou, Z. Q. Sheng, W. Xiao, Appl. Surf. Sci., 2018, 430, 218-224.

[32] P. Wang, Y. Sheng, F. Z. Wang, H. G. Yu, Appl. Catal. B, 2018, 220, 561-569.

[33] L. S. Meng, Z. Y. Chen, Z. Y. Ma, S. He, Y. D. Hou, H. H. Li, R. S. Yuan, X. H. Huang, X. X. Wang, X. C. Wang, J. L. Long, Energy Environ. Sci,, 2018, 11, 294-298.

[34] C. Marchal, T. Cottineau, M. G. Mendez-Medrano, C. Colbeau-Justin, V. Caps, V. Keller, Adv. Energy Mater., 2018, 8, 1702142.

[35] F. Guo, W. L. Shi, C. Zhu, H. Li, Z. H. Kang, Appl. Catal. B, 2018, 226, 412-420.

[36] M. Y. Xing, B. C. Qiu, M. M. Du, Q. H. Zhu, L. Z. Wang, J. L. Zhang, $A d v$. Funct. Mater., 2017, 27, 1702624

[37] B. Lin, J. Li, B. Xu, X. Yan, B. Yang, J. Wei, G. Yang, Appl. Catal. B, 2019, 243, 94-105.

[38] W. Liu, J. Shen, Q. Q. Liu, X. F. Yang, H. Tang, Appl. Surf. Sci., 2018, 462, 822-830.

[39] Y. H. Fu, Z. J. Li, Q. Q. Liu, X. F. Yang, H. Tang, Chin. J. Catal., 2017, $38,2160-2170$.

[40] Y. H. Fu, W. Liang, J. Q. Guo, H. Tang, S. S. Liu, Appl. Surf. Sci., 2018, 430, 234-242.

[41] L. Tian, X. F. Yang, X. K. Cui, Q. Q. Liu, H. Tang, Appl. Surf. Sci, 2019, $463,9-17$.

[42] W. Liu, J. Shen, X. F. Yang, Q. Q. Liu, H. Tang, Appl. Surf. Sci., 2018, 456, 369-378.
[43] F. X. Zhang, A. Yamakata, K. Maeda, Y. Moriya, T. Takata, J. Kubota, K. Teshima, S. Oishi, K. Domen, J. Am. Chem. Soc., 2012, 134, 8348-8351.

[44] X. F. Wang, R. Yu, P. Wang, F. Chen, H. G. Yu, Appl. Surf. Sci., 2015, 351, 66-73.

[45] S. E. Guo, Y. Q. Tang, Y. Xie, C. G. Tian, Q. M. Feng, W. Zhou, B. J. Jiang, Appl. Catal. B, 2017, 218, 664-671.

[46] W. J. Ong, L. K. Putri, Y. C. Tan, L. L. Tan, N. Li, Y. H. Ng, X. M. Wen, S. P. Chai, Nano Res., 2017, 10, 1673-1696.

[47] J. W. Fu, Q. L. Xu, J. X. Low, C. J. Jiang, J. G. Yu, Appl. Catal. B, 2019, 243, 556-565.

[48] D. Q. Zeng, T. Zhou, W. J. Ong, M. D. Wu, X. G. Duan, W. J. Xu, Y. Z. Chen, Y. A. Zhu, D. L. Peng, ACS Appl. Mater. Interfaces, 2019, 11, 5651-5660.

[49] H. W. Zhang, J. T. Ming, J. W. Zhao, Q. Gu, C. Xu, Z. X. Ding, R. S. Yuan, Z. Z. Zhang, H. X. Lin, X. X. Wang, J. L. Long, Angew. Chem. Int. Ed., 2019, 58, 7718-7722.

[50] Y. Wang, Z. Z. Zhang, L. N. Zhang, Z. B. Luo, J. N. Shen, H. X. Lin, J. L. Long, J. C. S. Wu, X. Z. Fu, X. X. Wang, C. Li, J. Am. Chem. Soc., 2018, 140, 14595-14598.

[51] J. Tian, Z. Wu, Z. Liu, C. Yu, K. Yang, L. Zhu, W. Huang, Y. Zhou, Chin. J. Catal., 2017, 38, 1899-1908.

[52] L. Tian, X. F. Yang, Q. Q. Liu, F. Q. Qu, H. Tang, Appl. Surf. Sci., 2018, 455, 403-409.

[53] H. Tang, Y. H. Fu, S. F. Chang, S. Y. Xie, G. G. Tang, Chin. J. Catal., 2017, 38, 337-347.

[54] X. F. Yang, L. Tian, X. L. Zhao, H. Tang, Q. Q. Liu, G. S. Li, Appl. Catal. $B, 2019,244,240-249$.

[55] Y. H. Ao, K. D. Wang, P. F. Wang, C. Wang, J. Hou, Appl. Catal. B, 2016, 194, 157-168.

[56] D. S. Li, H. C. Wang, H. Tang, X. F. Yang, Q. Q. Liu, ACS Sustain. Chem. Eng., 2019, 7, 8466-8474.

[57] X. A. Dong, W. D. Zhang, W. Cui, Y. J. Sun, H. W. Huang, Z. B. Wu, F. Dong, Catal. Sci. Technol., 2017, 7, 1324-1332.

[58] M. J. Liu, P. F. Xia, L. Y. Zhang, B. Cheng, J. G. Yu, ACS Sustain. Chem. Eng., 2018, 6, 10472-10480.

[59] L. Wang, N. Xu, X. Y. Pan, Y. S. He, X. X. Wang, W. Y. Su, Catal. Sci. Technol., 2018, 8, 1599-1605.

\title{
Co(II)-空穴和Pt-电子助催化剂协同作用增强P掺杂 $g-C_{3} N_{4}$ 光催化产氢性能
}

\author{
孙扣华 ${ }^{\mathrm{a}, \mathrm{c}, \dagger}$ ，沈 珺 ${ }^{\mathrm{b}, \dagger}$ ，刘芹芹 ${ }^{\mathrm{c}, \mathrm{d}}$, 唐 华 ${ }^{\mathrm{c}, \#}$, 张明义 ${ }^{\mathrm{d}}$, Syed Zulfiqar ${ }^{\mathrm{c}}$, 雷春生 ${ }^{\mathrm{a}, *}$ \\ a常州大学环境与安全工程学院, 江苏常州213164 \\ ${ }^{b}$ 苏州卫生职业技术学院药学院, 江苏苏州 215009 \\ c 江苏大学材料科学与工程学院, 江苏镇江 212013

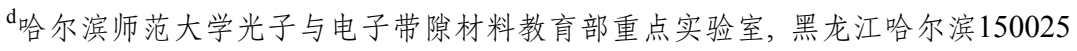

摘要: 石墨相氮化碳 $\left(\mathrm{g}-\mathrm{C}_{3} \mathrm{~N}_{4}\right)$ 是一种新型的有机半导体材料, 具有独特的层状结构、合适的能带位置、简单的制备方法以 及出色的稳定性等特点, 因而被广泛应用于光催化产氢领域. 但是, 较高的光生载流子的复合率和受限的迁移率大大地限 制了 $\mathrm{g}-\mathrm{C}_{3} \mathrm{~N}_{4}$ 的光催化产氢性能. 目前, 大量的研究证实块状 $\mathrm{g}-\mathrm{C}_{3} \mathrm{~N}_{4}$ 的液相剥离、表面改性、元素掺杂、与其他半导体复合 构筑异质结以及负载助催化剂等方法可以在一定程度上提高 $\mathrm{g}-\mathrm{C}_{3} \mathrm{~N}_{4}$ 的光催化产氢性能. 但是单一的 $\mathrm{g}-\mathrm{C}_{3} \mathrm{~N}_{4}$ 改性方法往往 并不能获得最理想的光催化产氢性能, 因此, 本文采用低温磷化法制备了二价钴 $\left(\mathrm{Co}(\mathrm{II})\right.$ ) 修饰的磷( $\mathrm{P}$ )掺杂的 $\mathrm{g}-\mathrm{C}_{3} \mathrm{~N}_{4}$ 纳米片 $(\mathrm{Co}(\mathrm{II}) / \mathrm{PCN})$, 同时实现了掺杂P原子和负载空穴助催化剂 $\mathrm{Co}(\mathrm{II})$, 该催化剂表现出出色的光催化产氢性能. 在光催化制氢过 程中, 铂 $(\mathrm{Pt})$ 纳米颗粒作为电子助催化剂成功的负载在 $\mathrm{Co}(\mathrm{II}) / \mathrm{PCN}$ 上. 光催化实验结果表明, 最佳的 $\mathrm{Pt} / \mathrm{Co}(\mathrm{II}) / \mathrm{PCN}$ 复合材料 光催化产氢速率达到 $774 \mu \mathrm{mol} \cdot \mathrm{g}^{-1} \cdot \mathrm{h}^{-1}$, 比纯相的 $\mathrm{g}-\mathrm{C}_{3} \mathrm{~N}_{4}$ 纳米片 $\left(89.2 \mu \mathrm{mol} \cdot \mathrm{g}^{-1} \cdot \mathrm{h}^{-1}\right)$ 提升 8.6 倍. 同时优化的光催化剂具有良好 的光催化稳定性, 并在 $402 \mathrm{~nm}$ 处具有 $2.76 \%$ 的量子产率. XRD, TEM, STEM-EDX和AFM结果证明, 成功制备了纳米片状形 貌的 $\mathrm{g}-\mathrm{C}_{3} \mathrm{~N}_{4}$ 及其复合材料, 催化剂中均匀的分布着 $\mathrm{Co}$ 和P元素. 通过XPS证明了 $\mathrm{P}-\mathrm{N}$ 的存在以及 $\mathrm{Co}(\mathrm{II})$ 的存在, 并且 $\mathrm{Co}(\mathrm{II})$ 是 
以一种无定型的 $\mathrm{CoOOH}$ 的形式吸附在 $\mathrm{g}-\mathrm{C}_{3} \mathrm{~N}_{4}$ 表面. 光照后的TEM证明Pt颗粒成功的负载在 $\mathrm{Co}(\mathrm{II}) / \mathrm{PCN}$ 表面. UV-vis DRS 表明, 由于 $\mathrm{P}$ 的掺杂以及 $\mathrm{Co}(\mathrm{II})$ 的修饰, $\mathrm{Co}(\mathrm{II}) / \mathrm{PCN}$ 相比于 $\mathrm{g}-\mathrm{C}_{3} \mathrm{~N}_{4}$ 纳米片在可见光区域光吸收有了明显的增强. 通过稳态和 瞬态光致发光光谱分析, 同时结合电化学分析表征 $(i-t 、 E I S)$ 以及电子顺磁共振技术分析, 证实了 $\mathrm{Co}(\mathrm{II}) / \mathrm{PCN}$ 高效光催化性 能的原因可能是由于更高效的光生载流子分离效率. 本文对 $\mathrm{Pt} / \mathrm{Co}(\mathrm{II}) / \mathrm{PCN}$ 可能的光催化增强机理提出了设想. $\mathrm{P}$ 的掺杂可 以优化 $\mathrm{g}-\mathrm{C}_{3} \mathrm{~N}_{4}$ 的电子结构, 提高其光生载流子分离效率. 而以Pt作为电子助催化剂, 可以有效地捕获P掺杂的 $\mathrm{g}-\mathrm{C}_{3} \mathrm{~N}_{4}$ 导带中 的光生电子, 进而发生水还原产氢反应; 以 $\mathrm{Co}(\mathrm{II})$ 作为空穴助催化剂, 可以捕获价带中的光生空穴, 进而发生三乙醇胺氧化 反应. 通过采用不同功能的助催化剂, 实现 $\mathrm{P}$ 掺杂 $\mathrm{g}-\mathrm{C}_{3} \mathrm{~N}_{4}$ 光生电子空穴的定向分流, 促进了 $\mathrm{P}$ 掺杂 $\mathrm{g}-\mathrm{C}_{3} \mathrm{~N}_{4}$ 的光生载流子的分 离, 从而提高催化剂的光催化产氢性能. 本文可以为设计具有空穴-电子双助催化剂的光催化产氢系统提供一个新的思路. 关键词: 光催化产氢; 空穴助催化剂; 电子助催化剂; 磷掺杂氮化碳

收稿日期: 2019-05-30. 接受日期: 2019-06-22. 出版日期: 2020-01-05.

*通讯联系人. 电话: 15995017856; 电子信箱:qiuyu_lei@126.com

\#通讯联系人. 电子信箱: huatang79@163.com

†共同第一作者.

基金来源：国家自然科学基金(51672113); 江苏省青蓝工程基金(201611).

本文的电子版全文由Elsevier出版社在ScienceDirect上出版(http://www.sciencedirect.com/science/journal/18722067). 